\title{
ANALISIS KEMAMPUAN BERPIKIR KREATIF MATEMATIK SISWA SMP PADA MATERI SEGITIGA DAN SEGIEMPAT
}

\author{
Risma Amelia ${ }^{1}$, Usman Aripin², Nurul Hidayani ${ }^{3}$ \\ 1,2,3 IKIP Siliwangi, Jl. Terusan Jenderal Sudirman, Cimahi, Jawa Barat, Indonesia \\ ${ }^{1}$ risma.gembil@gmail.com, ${ }^{2}$ usman.aripin@ikipsiliwangi, ${ }^{3}$ nurul.hidayani@gmail.com
}

\begin{abstract}
This study aims to analyze the creative thinking abilities of junior high school students in the Triangle and Quadrilateral material. The method used in the preliminary study is descriptive qualitative, which aims to analyze the ability of students to solve triangular and quadrilateral problems seen from the level of mathematical creative thinking ability of junior high school students. The population in this study were junior high school students in the city of Cimahi and the sample for this study were 36 eighth grade students in one of the junior high schools in the city of Cimahi. The instrument of creative thinking ability test is given as many as 5 questions with the type of description. Then the results obtained are the level of mathematical creative thinking ability of junior high school students in the city of Cimahi based on the written test is still relatively low.
\end{abstract}

Keywords: Creative Thinking

\begin{abstract}
Abstrak
Penelitian ini bertujuan untuk menganalisis kemampuan berpikir kreatif siswa SMP pada materi Segitiga dan Segiempat. Metode yang digunakan dalam studi pendahuluan adalah kualitatif deskriptif, yang bertujuan untuk menganalisis kemampuan berpikir matematik siswa pada materi segitiga dan segiempat. Populasi dalam penelitian ini adalah siswa SMP di kota Cimahi dan sampel untuk penelitian ini adalah 36 siswa kelas VIII di salah satu Sekolah Menengah Pertama di Cimahi. Adapun intrumen tes kemampuan berpikir kreatif yang diberikan sebanyak 5 soal dengan jenis uraian. Kemudian hasil yang diperoleh adalah pencapaian tes kemampuan berpikir kreatif matematik masih dibawah rata-rata kriteria ketuntasan minimum (KKM).
\end{abstract}

Kata Kunci: Berfikir Kreatif

How to cite: Amelia, R., Aripin, U., Hidayani, R. (2018). Analisis Kemampuan Berpikir Kreatif Matematik Siswa SMP pada Materi Segitiga dan Segiempat. JPMI - Jurnal Pembelajaran Matematika Inovatif, 1 (6), XX-XX.

\section{PENDAHULUAN}

Banyak siswa di beberapa jenjang pendidikan menganggap bahwa matematika itu sulit dan akan menimbulkan beberapa persoalan seperti rendahnya hasil belajar siswa. Seiring dengan adanya inovasi-inovasi baru terhadap proses pembelajaran dan didukung pula oleh teknologi yang memadai maka akan menjadikan proses belajar semakin mengalami kemajuan yang lebih baik lagi. Rendah nya hasil belajar matematika tentunya banyak faktor yang mempengaruhinya baik itu siswa, guru, lingkungan sekitarnya. Selain itu menurut Hidayat, Heridman, Aripin, Yuliani \& Maya (2018) ketercapaian pengembangan kemampuan matematika yang dimiliki peserta didik tidak akan lepas dari pendidiknya. Seorang pendidik dituntut untuk memiliki kemampuan penalaran kreatif matematis yang baik. 
Riana (2012:1) mengungkapkan bahwa, "Tujuan efektif belajar matematika di sekolah adalah sikap kritis, cermat, obyektif, dan terbuka, menghargai keindahan matematika serta rasa ingin tahu dan senang belajar matematika". Oleh karena itu, matematika penting untuk dipahami oleh setiap masyarakat supaya selalu cerdas dan tanggap dalam menyelesaikan permasalahan kehidupannya.

Menurut Boyer dan Carl (Hendriana dan Sumarmo, 2014:12) bahwa "Matematika bukanlah produk dari metode ilmiah, tetapi merupakan buah pikir manusia yang kebenarannya bersifat umum (deduktif). Menurut Schonfeld (Amelia, 2015) matematika merupakan proses yang aktif, dinamik, generative dan ekdploratif. Kebenarannya tidak hanya bergantung pada metode ilmiah yang didalamnya terdapat proses induktif. Kebenaran matematika pada dasarnya bersifat koheren yaitu kebenaran yang didasarkan pada kebenaran-kebenaran”.

Pendidikan menjadi sangat penting untuk diperhatikan dalam pembangunan di setiap negara. Suatu negara dikatakan maju atau tidaknya, salah satu faktor penimbangnya adalah kualitas pendidikan di negara tersebut. Pendidikan memiliki peranan yang sangat menentukan bagi perkembangan dan peningkatan sumber daya manusia sehingga dapat menciptakan sebuah peradaban yang menjadi identitas bagi negara itu sendiri

Kadir (2006:2) mengemukakan bahwa "Pembelajaran matematika dimaknai sebagai pembelajaran yang permasalahannya hanya dapat diselesaikan dengan satu cara dan hanya mendapatkan satu hasil". Suasana ini menjadi sangat sistematis merasuk pada diri siswa, manakala pandangan guru matematikanya di SD sama dengan pandangan guru di sekolah jenjang selanjutnya. Pandangan semacam ini semakin intens bila dari buku yang mereka baca menghasilkan persepsi yang seragam pula.Dengan demikian guru dituntut untuk mengkemas suatu pembelajaran secara optimal, dan yang paling utama adalah melibatkan siswa secara aktif. Seperti dikemukakan oleh Krismanto (2003:1) bahwa "strategi yang diambil hendaklah guru mampu melibatkan siswa yang aktif dalam proses belajar mengajar sehingga dapat meningkatkan daya kreativitas siswa".

Kreativitas merupakan suatu hal yang kurang diperhatikan dalam pembelajaran matematika. Selama ini siswa belajar mengasah logika dan kemampuan komputasi sehingga kreativitas siswa tidak dapat tegali dengan optimal pada saat pembelajaran di kelas. Pada pendahuluan 1 Kurikulum 2006 menyebutkan bahwa kemampuan berpikir kreatif sangat diperlukan untuk menguasai dan mencipta teknologi di masa depan. Selain itu disebutkan bahwa mata pelajaran matematika diberikan kepada setiap jenjang pendidikan agar peserta didik mampu berpikir logis, analitis, sistematis, kritis dan kreatif, dalam menyelesaikan persoalan kehidupannya. Kompetensi tersebut dikembangkan dalam diri siswa, agar siswa memiliki kemampuan mengelola, menginterpretasikan dan memanfaatkan informasi yang ada untuk bertahan hidup pada keadaan yang selalu dinamis dan kompetitif.

Pehkonen (Saefudin, 2012) mengatkan bahwa kemampuan berpikir kreatif merupakan kombinasi antara berpikir logis dan berpikir divergen yan sesuai dengan intuisi dalam kesadaran. Oleh karenanya, berpikir kreatif melibatkan logika dan intuisi secara bersama-sama. Selain itu berpikir kreatif merupakan kesatuan dari berpikir logis dan berpikir divergen agar menghasilkan gagasan ataupun sesuatu yang baru. Sesuatu yang baru tersebut merupakan salah satu implikasi dari berpikir kreatif dalam matematika.

Babij (Fardah, 2012) menyebutkan bahwa berpikir kreatif terfokus pada aspek kelancaran (fluency), keluwesan (flexibility), keaslian (originality), dan keterincian (elaboration). 
Kelancaran dapat diartikan keterampilan siswa dalam menyelesaikan permasalahan yang ada, sedangkan keluwesan merupakan kemampuan siswa dalam memberikan berbagai cara penyelesaian. Selain itu keaslian merupan cara siswa menemukan atau memberikan sebuah cara penyelesaian yang tidak lazim sedangkan keterician merupakan kemampuan memperinci suatu permasalahan ataupun memberikan masukan atau tambahan suatu gagasan sehingga dapat memperkaya pengetahuan.

Berdasarkan pernyataan Noer (2009:1) mengungkapkan bahwa "pembelajaran matematika di SMP kota Bandar Lampung secara umum terbiasa dengan urutan langkah-langkah pembelajaran sebagai berikut : (1) diajarkan teori/definisi/teorema; (2) diberikan contohcontoh; (3) diberikan latihan soal. Dengan kondisi yang demikian, kemampuan kreatif siswa kurang berkembang. Sebagai negara berkembang kita sangatlah membutuhkan orang-orang kreatif yang mampu memperkaya khazanah ilmu pengetahuan dan memberikan manfaat untuk kemajuan negara agar menjadi bangsa yang mandiri. Oleh karenanya melalui pendidikanlah salah satu alternatif untuk meningkatkan kreatifitas sumberdaya manusia.

Menyikapi hal tersebut maka peneliti perlu melakukan studi pendahuluan untuk mengetahui kemampuan berpikir kreatif matematik siswa SMP di kota Cimahi dalam materi kubus dan Balok.

\section{METODE}

Penelitian ini tergolong dalam penelitian kualitatif deskriptif yang bertujuan untuk menganalisis kemampuan siswa dalam menyelesaikan soal segitiga dan segiempat dilihat dari tingkat kemampuan berpikir kreatif matematik siswa SMP. Data penelitian ini berupa jawaban tertulis yang diperoleh dari tes tertulis Populasi dalam penelitian ini adalah siswa SMP di kota Cimahi dan sampel untuk penelitian ini adalah siswa kelas VIII sebanyak 36 orang di salah satu SMP di kota Cimahi dengan kemampuan yang beragam yaitu tinggi, sedang dan rendah. Adapun instrumen yang diberikan pada siswa sebanyak 5 soal dengan bentuk uraian. Instrument yang digunakan dalam studi pendahuluan adalah instrument yang telah diuji coba kan oleh peneliti Pujianingsih (2017), instrument tersebut merupakan instrumen yang sudah teruji validitas, reliabilitas, indeks kesukaran serta daya pembedanya.

\section{HASIL DAN PEMBAHASAN}

\section{Hasil}

Penelitian ini dilakukan pada 36 orang siswa kelas VIII-E di SMP Pasundan 1 Cimahi. Berikut ini adalah tabel persentase jawaban siswa tiap butir soal dan tiap indikator serta contoh-contoh jawaban siswa dengan nilai tinggi, sedang dan rendah.

Tabel 1. Persentase jawaban siswa tiap butir soal dan indikator

\begin{tabular}{|c|l|c|}
\hline $\begin{array}{c}\text { No. } \\
\text { Soal }\end{array}$ & \multicolumn{1}{|c|}{ Indikator } & $\begin{array}{c}\text { Persentase } \\
\text { Jawaban } \\
\text { Benar }\end{array}$ \\
\hline 1. & Fluency & $94 \%$ \\
\hline 2. & Originality & $38 \%$ \\
\hline 3. & Flexibility & $13 \%$ \\
\hline 4. & Redefinition & $33 \%$ \\
\hline 5. & Elaboration & $27 \%$ \\
\hline
\end{tabular}

A. Analisis Soal Nomor 1

Pertanyaan No. 1: 
Gambarkan minimal 3 segitiga yang berbeda jenisnya yang memiliki keliling yang sama yaitu $12 \mathrm{~cm}$ !

Indikator kemampuan berpikir kreatif matematik : Siswa dapat memberikan penjelasan dengan lancar (Fluency) tentang jenis-jenis segitiga.

Jawaban siswa 1 (Berkemampuan tinggi):

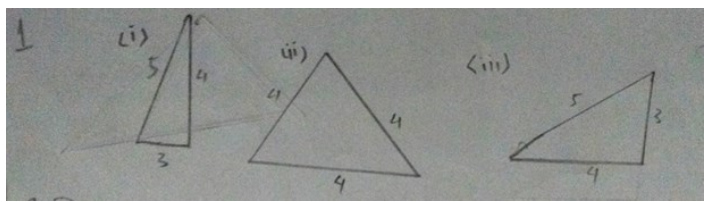

Analisis:

Gambar1. Jawaban Siswa Berkemampuan Tinggi

Siswa sudah mampu menggambar segitiga yang berbeda jenisnya tetapi memiliki keliling yang sama yaitu $12 \mathrm{~cm}$, karena siswa mengetahui rumus keliling segitiga tersebut. Sehingga siswa lancar membuat segitiga dengan bentuk yang berbeda dan keliling yang sama.

Jawaban siswa II (Berkemampuan Sedang):

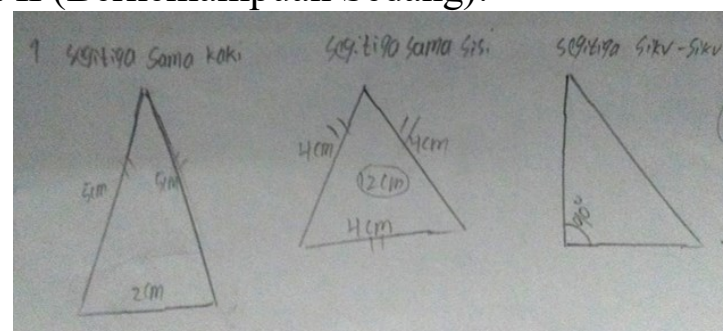

Gambar 2. Jawaban Siswa Berkemampuan Sedang

Analisis:

Siswa sudah mampu menggambar bentuk-bentuk segitiga dengan berbeda jenis dan keliling yang sama dan mengetahui rumus, namun siswa tersebut bingung dengan bentuk segitiga yang terakhir ia gambar, ia menggambarkan segitiga siku-siku, sehingga ia hanya menuliskan keterangan pada segitiga tersebut dengan sudut 90 derajat.

Jawaban siswa III (Berkemampuan Rendah):

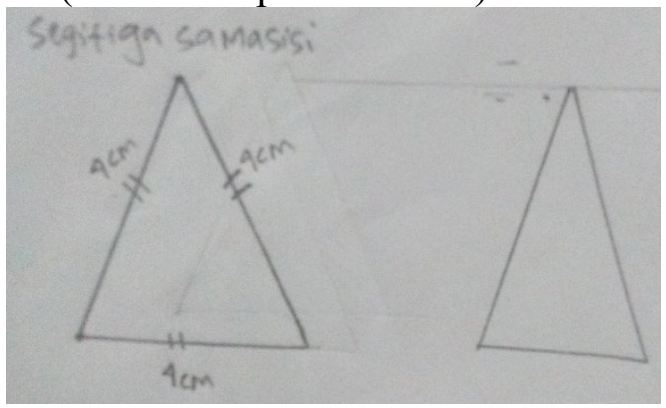

Gambar 3. Jawaban Siswa Berkemampuan Rendah

Analisis:

Siswa tersebut mengatahui rumus keliling segitiga, namun siswa bingung menggambar segitiga dengan bentuk yang berbeda.

B. Analisis Soal Nomor 2

Pertanyaan No.2:

Jelaskan persamaan dan perbedaan bangun datar segiempat berikut. 

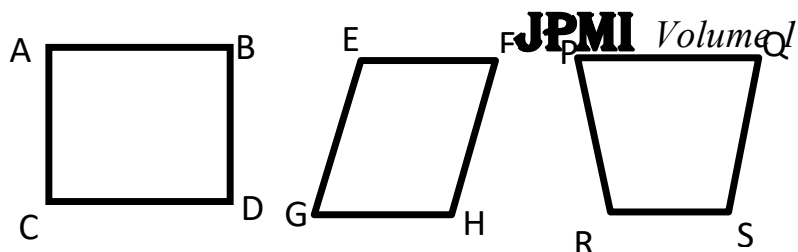

Gambar 4. Soal Nomor 2

Indikator Kemampuan berpikir kreatif: Siswa dapat memberikan jawaban dengan metodanya sendiri (originality).

Jawaban siswa I (Berkemampuan Tinggi):

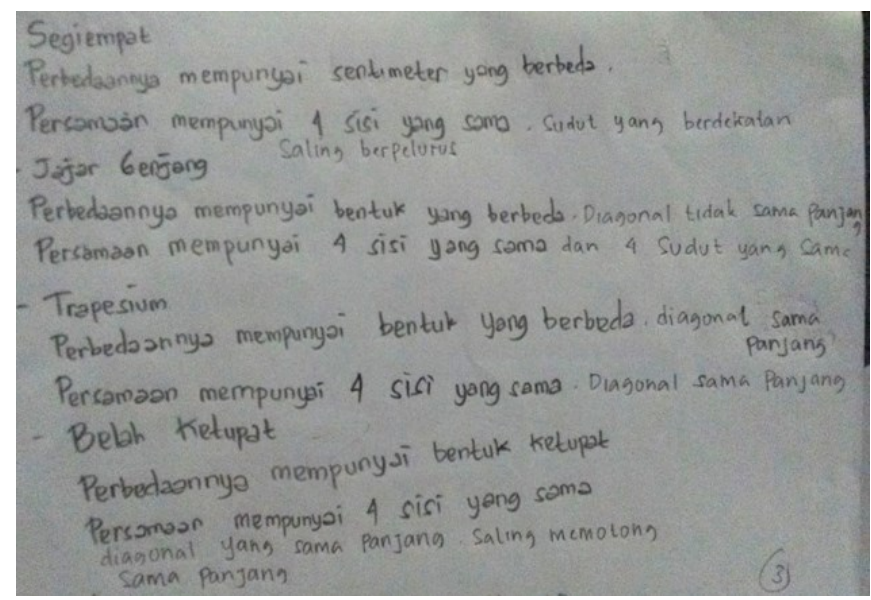

Gambar 5. Jawaban Siswa Berkemampuan Tinggi

Analisis:

Siswa tersebut sudah menjawab pertanyaan dengan baik, siswa sudah mampu menyebutkan nama persamaan dan perbedaan dari keempat bangun datar tersebut dengan metodenya sendiri, namun ada beberapa keterangan yang kurang lengkap seperti menyebutkan untuk trapesium dengan diagonal yang sama panjang dan saling memotong dengan sama panjang

Jawaban siswa II (Berkemampuan Sedang):

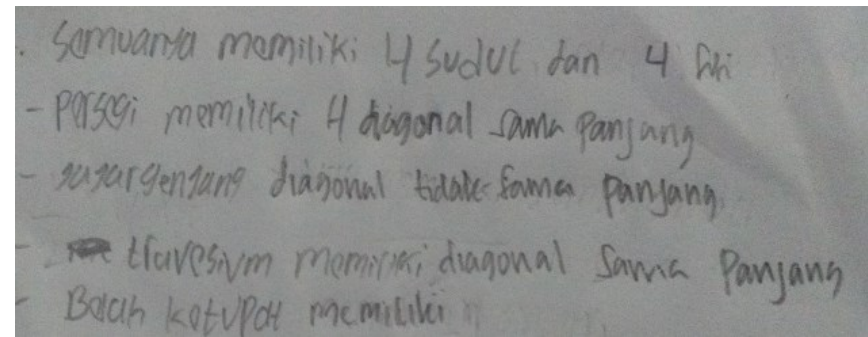

Analisis:

Gambar 6. Jawaban Siswa Berkemampuan Sedang

Siswa sudah mengetahui dan menyebutkan nama bangun datar tersebut, tetapi siswa sudah mengetahui persamaan dari bangun datar tersebut. Namun pada perbedaan siswa hanya bisa menyebutkan perbedaan pada diagonalnya saja, sehingga kurang lengkap.

Jawaban siswa III (Berkemampuan Rendah): 
Analisis:

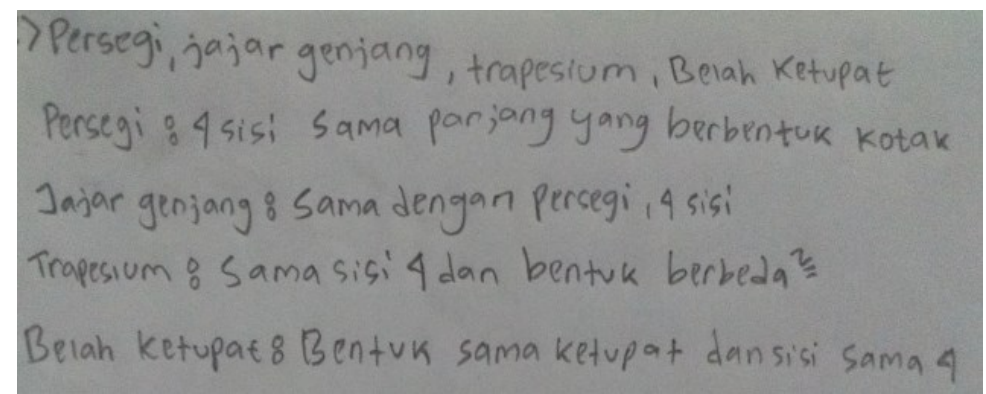

Gambar 7. Jawaban Siswa Berkemampuan Rendah

Siswa hanya mampu menyebutkan nama bangun datar dengan benar, untuk persamaan dan perbedaan siswa hanya menyebutkan persamaan dari keempat bangun datarnya saja, yaitu memiliki 4 sisi.

C. Analisis Soal Nomor 3

Pertanyaan No. 3:

\section{C}

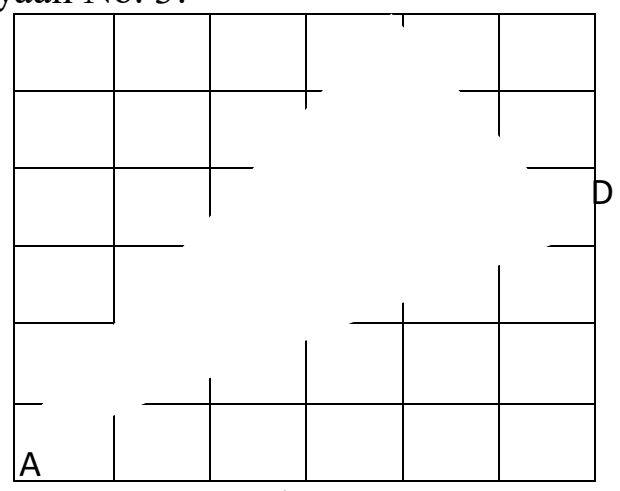

Gambar 8. Soal Nomor 3

Tentukan luas daerah yang diwarnai. Jelaskan minimal dua cara perhitungannya!

Indikator kemampuan berpikir kreatif: Siswa dapat memberikan jawaban yang bervariasi (Flexibility)

Jawaban siswa I (Berkemampuan Tinggi):

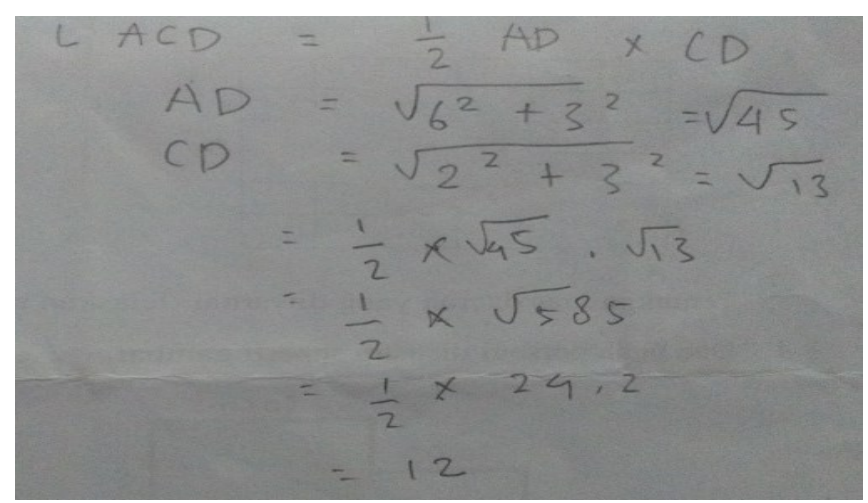

Analisis:

Gambar 9. Jawaban Siswa Berkemampuan Tinggi

Siswa sudah mampu membuat ide dari gambar pada soal. Siswa tersebut membuat ide bahwa $\mathrm{L} \triangle \mathrm{ACD}=\frac{1}{2} \mathrm{AD} \times \mathrm{CD}$ dan $\mathrm{AD}$ didapat 6 dan 3 dihitung pada kotak yang berbentuk persegi , sedangkan untuk CD didapat dari 2 dan 3 . Siswa tersebut membuat ide dengan memakai 
theorem phytagoras dan siswa mampu memecahkan masalah dengan ide nya. Namun siswa hanya mampu menyelesaikan soal tersebut dengan 1 cara yang benar.

Jawaban siswa II (Berkemampuan Sedang):

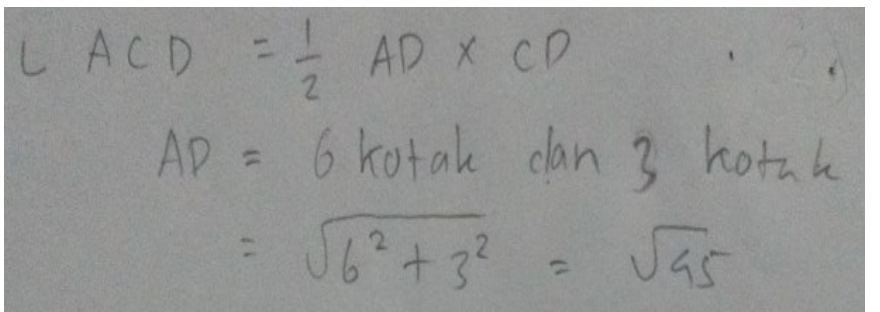

Analisis:

Gambar 10. Jawaban Siswa Berkemampuan Sedang

Siswa sudah mampu membuat ide dari gambar yang ada pada soal, siswa memecahkan masalah dengan theorem phytagoras sama dengan siswa I, pada saat menemukan ide tersebut siswa belum mampu menyelesaikan, karena siswa tersebut bingung menghitung operasi akar pangkat, sehingga siswa tidak menuntaskan pekerjaannya.

Jawaban siswa III (Berkemampuan Rendah):

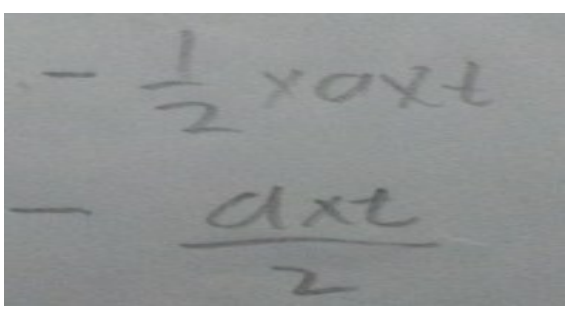

Analisis:

Gambar 11 .Jawaban Siswa Berkemampuan Rendah

Siswa hanya mampu menyebutkan luas pada segitiga, siswa tidak mencerna dengan baik dan tidak memunculkan ide pada gambar yang ada pada soal.

D. Analisis Soal Nomor 4

Pertanyaan No. 4:

Dua buah persegi disusun seperti gambar

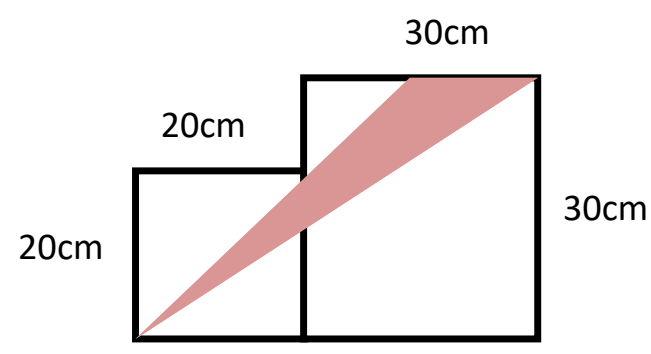

Gambar12. Soal No.4

Carilah dengan caramu sendiri bagaimana menghitung luas deerah yang diwarnai!

Indikator kemampuan berpikir kreatif matematik siswa: Siswa dapat merumuskan kembali (redefinition) tentang menghitung luas segiempat.

Jawaban siswa I (Berkemampuan Tinggi): 


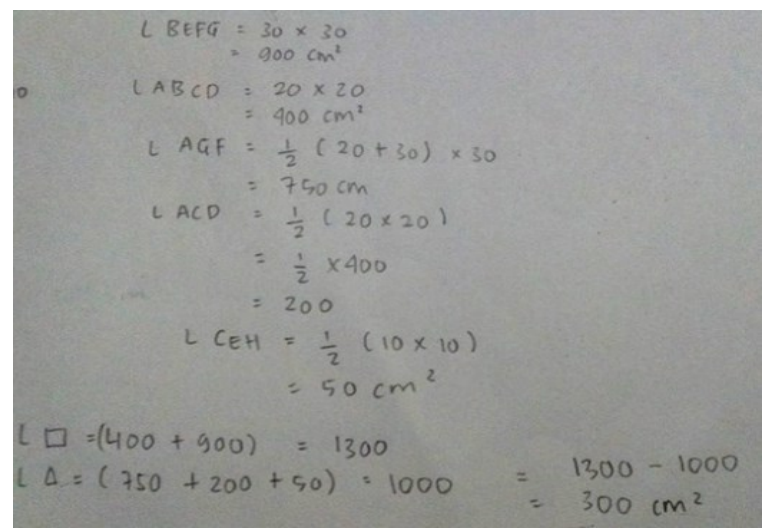

Gambar13. Jawaban Siswa Berkemampuan Tinggi

Analisis:

Siswa sudah mampu membuat ide, namun siswa ini mampu merumuskan kembali bahwa luas segiempat yang ia dapat dikurangi dengan jumlah $L \Delta$ lain yang telah ia temukan, sehingga didapat hasil akhirnya. Dan siswa tersebut mampu merumuskan kembali tentang menghitung luas segi empat.

Jawaban siswa II (Berkemampuan Sedang):

Analisis:

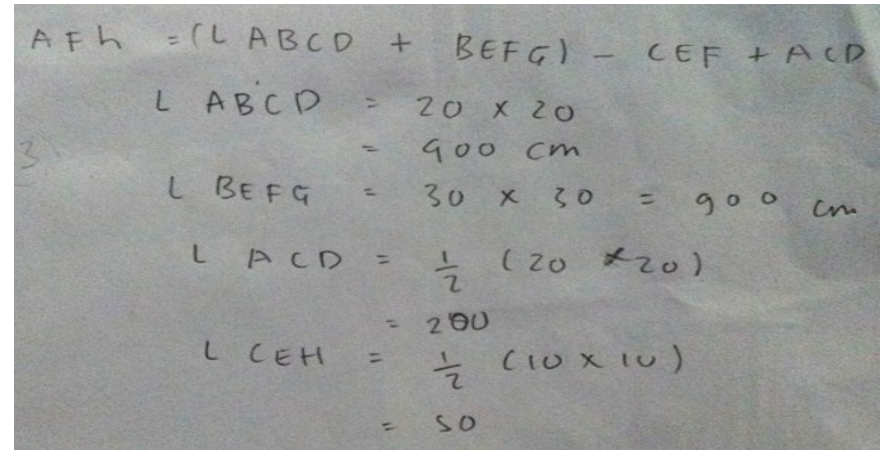

Gambar14. Jawaban Siswa Berkemampuan Sedang

Siswa sudah mampu membuat ide dengan caranya sendiri siswa membuat titik-titik pada gambar yang ada pada soal, siswa membuat gambar segitiga dengan $\triangle \mathrm{AFH}$, namun siswa tersebut hanya mampu menyelesaikan dengan mencari luas bangun yang tidak diwarnai. Siswa ini belum mampu merumuskan kembali tentang menghitung luas segi empat.

Jawaban siswa III (Berkemampuan Rendah):

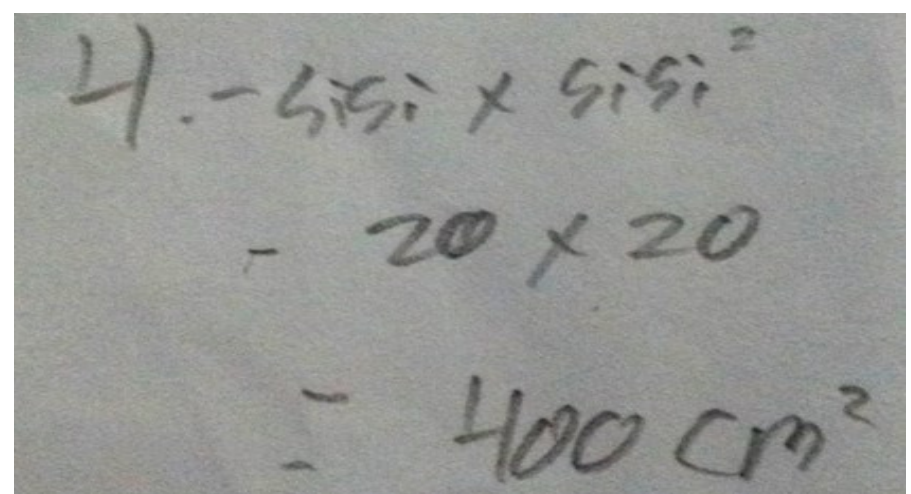

Gambar 15. Jawaban Siswa Berkemampuan Rendah 
Analisis:

Siswa hanya mampu menghitung luas dari segi empat tersebut. Siswa belum mampu membuat ide dari gambar yang diketahui oleh soal. Sehingga siswa tidak bisa menyelesaikan soal tersebut.

E. Analisis soal nomor 5

Pertanyaan No. 5:

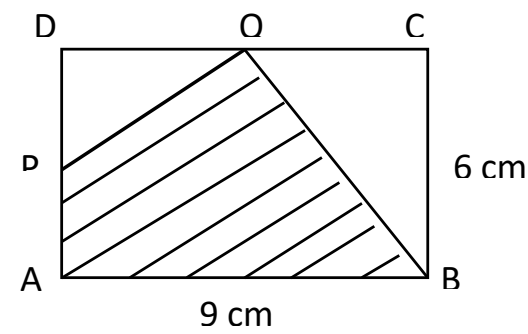

Gambar16. Soal Nomor 5

Susunlah langkah-langkah menentukan luas ABQP!

Indikator kemampuan berpikir kreatif matematik: Siswa dapat menguraikan langkah-langkah (elaboration) menghitung luas segiempat dan segitiga.

Jawaban siswa I (Berkemampuan Tinggi):

Analisis:

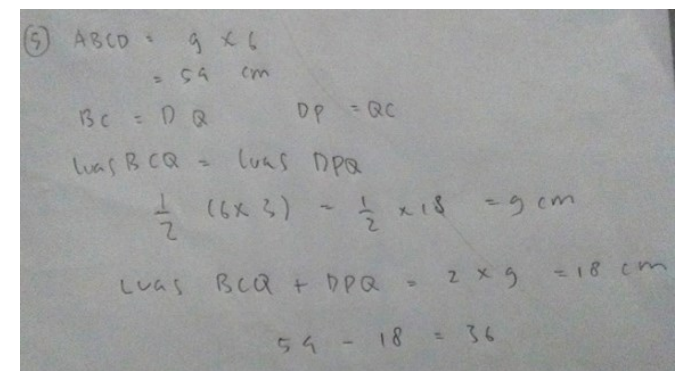

Siswa sudah mampu memunculkan ide bahwa panjang $\mathrm{BC}=\mathrm{DQ}$ dan panjang $\mathrm{DP}=\mathrm{QC}$, dan luas BCQ = luas DPQ. Sehingga untuk tahap selanjutnya siswa mampu melanjutkan langkahlangkah penyelesaiannya dengan tepat. Dan siswa mampu menguraikan langkah-langkah untuk menentukan luas yang diarsir pada soal.

Jawaban siswa II (Berkemampuan Sedang):

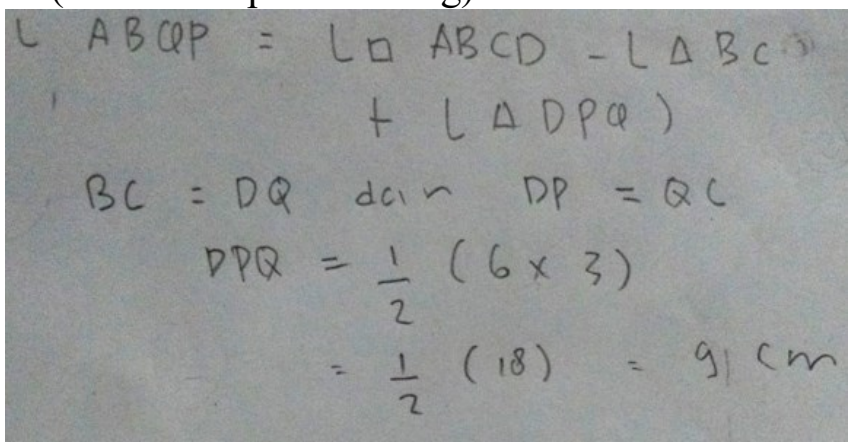

Analisis:

Gambar18. Jawaban Siswa Berkemampuan Sedang

Siswa sudah mampu memunculkan ide pada soal tersebut, namun pada proses pengerjaannya siswa tersebut tidak melanjutkan pekerjaannya, siswa bingung menentukan luas $\Delta$ yang lainnya. Sehingga siswa tidak melanjutkan. 
Jawaban siswa III (Berkemampuan Rendah):

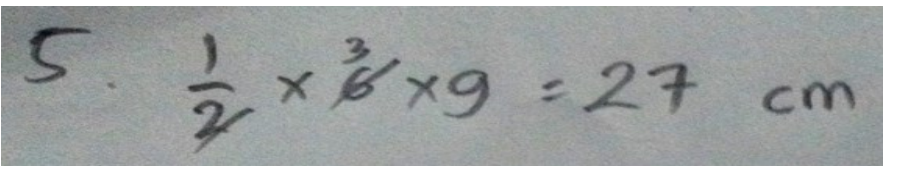

Analisis:

Gambar 19. Jawaban Siswa Berkemampuan Rendah

Siswa hanya mampu menghitung luas segitiga dengan rumus $\frac{1}{2} \times a \times t$. siswa bingung memunculkan ide sehingga siswa belum mampu menguraikan langkah-langkah untuk menentukan luas yang diarsir pada soal.

\section{Pembahasan}

Dari setiap soal yang sudah dianalisis dapat kita lihat bahwa siswa berkemampuan sedang dan rendah masih terdapat kesulitan dalam menyelesaikan persoalan yang diberikan. Hal ini terjadi karena siswa belum memahami permasalahan yang diberikan, terbukti dari jawaban yang diberikan siswa masih kurangnya pengetahuan tentang materi yang sedang dibicarakan. Kurangnya pengetahuan bisa terjadi karena siswa belum memahami materi tersebut pada saat pembelajaran atau karena kurangnya latihan sehingga kemampuannya kurang terlatih. Hal ini ditegaskan oleh Fitria dkk (2018) Kemampuan adalah kecakapan atau potensi menguasai suatu keahlian yang merupakan bawaan sejak lahir atau merupakan hasil latihan maupun praktek dan digunakan untuk mengerjakan sesuatu yang diwujudkan melalui tindakannya.

Tidak hanya harus memiliki pengetahuan, tetapi siswa harus dapat memunculkan ide kreatifnya dalam menyelesaiakan persamasalah. Berdasarkan hasil yang didapat kebayakan siswa masih kesulitan dalam memunculkan ide awal dalam menyelesaikan persamasalahan. Hal ini terjadi karena siswa belum terbiasa dengan soal-soal kemampuan berpikir kreatif dan kurangnya daya juang dalam menyelesaikan masalah. Selian itu, hasil studi TIMSS pada tahun 2015 (Aripin \& Purwasih, 2017) mengungkapkan bahwa siswa Indonesia perlu penguatan kemampuan mengintegrasikan informasi, menarik simpulan, serta menggeneralisir pengetahuan yang dimiliki ke hal-hal yang lain. Siswa Indonesia masih perlu dikembangkan lagi untuk kemampuan matematika tingkat tinggi, salah satu berpikir tingkat tinggi adalah kemampuan berpikir kreatif. Oleh karena itu masih perlu adanya penelitian khusus untuk mengatasi permasalahan ini.

Selain itu siswa masih kesulitan menyelesaikan masalah meskipun sudah mampu merumuskan ide awal. Hal ini terjadi karena sebagian siswa merasa kurang waktu dalam menyelesaikan masalah selain itu masih merasa kesulitan mencari unsur-unsur yang ditanyakan sehingga kesulitan dalam menyelesaikan permasalahan. Hal ini sejalan dengan pendapat Amelia (2016) proses matematika dan penarikan kesimpulan memerlukan pemikiran, pemahaman dan berpikir tingkat tinggi.

Berdasarkan beberapa contoh hasil jawaban siswa, dapat disimpulkan bahwa siswa belum memahami konsep dari segitiga dan segiempat, siswa belum terampil dalam memunculkan ide dan belum mampu memecahkan masalah. Sehingga siswa belum dapat memberikan penjelasan dengan lancar (Fluency), Siswa belum dapat memberikan jawaban dengan metodanya sendiri (originality), siswa belum dapat memberikan jawaban yang bervariasi (Flexibility), siswa belum dapat merumuskan kembali (redefinition), siswa belum dapat menguraikan langkahlangkah (elaboration). 


\section{KESIMPULAN}

Berdasarkan hasil dan pembahasan, dapat kita simpulkan beberapa jawaban yang kurang tepat dalam menjawab soal.

a. Ada beberapa siswa yang mengalami kesulitan untuk menentukan bangun datar segitiga dengan bentuk yang berbeda namun memilik keliling yang sama.

b. Kebanyakan siswa tidak ingat dengan rumus yang telah diberikan.

c. Kebanyakan siswa kesulitan memunculkan ide pertama pada soal yang diberikan.

d. Siswa kesulitan dalam memecahkan masalah walaupun siswa tersebut sudah menemukan ide nya.

e. Sebagian besar siswa belum mampu membuat tulisan matematika yang sesuai dengan apa yang ditujukan.

Dengan begitu, sesuai dengan hasil analisis dari sampel siswa kelas VIII di salah satu SMP di kota Cimahi dengan berkemampuan tinggi, sedang dan rendah menunjukkan bahwa pencapaian tes kemampuan berpikir kreatif matematik masih dibawah rata-rata kriteria ketuntasan minimum (KKM).

\section{DAFTAR PUSTAKA}

Aripin, U., \& Purwasih, R. (2017). Penerapan Pembelajaran Berbasis Alternative Solutions Worksheet Untuk Meningkatkan Kemampuan Berpikir Kreatif. AKSIOMA: Jurnal Program Studi Pendidikan Matematika, 6(2), 225-233.

Amelia, R. (2016). Pencapaian kemampuan penalaran matematis siswa SMP dengan menggunakan metode pembelajaran inkuiri terbimbing. P2M STKIP Siliwangi, 2(1), 98-105.

BSNP. Standar Isi dan Standar Kompetensi Lulusan SD/MI. Jakarta: Kemendiknas, 2006.

Fardah (2012). Analisis Proses dan Kemampuan Berpikir Kreatif Siswa dalam Matematika Melalui Tugas Open-Ended. JURNAL KREANO, ISSN : 2086-2334 Diterbitkan oleh Jurusan Matematika FMIPA UNNES Vol. 3, No. 2.

Fitria, N. F. N., Hidayani, N., Hendriana, H., \& Amelia, R. (2018). Analisis Kemampuan Pemecahan Masalah Matematik Siswa SMP dengan Materi Segitiga dan Segiempat. EDUMATICA Jurnal Pendidikan Matematika, 8(01), 49-57.

Hendriana, H dan Sumarmo, U. (2014). Penilaian Pembelajaran Matematika. Bandung: PT Rafika Aditama.

Hidayat, W., Herdiman, I., Aripin, U., Yuliani, A., \& Maya, R. (2018). Adversity Quotient (AQ) dan Penalaran Kreatif Matematis Mahasiswa Calon Guru. Jurnal Elemen, 4(2), 230242. 
1154 Amelia, Aripin, \& Hidayani, Analisis Kemampuan Berpikir Kreatif Matematis ...

Kadir (2006). Algoritma Jurnal Matematika dan Pendidikan Matematika "Pembelajaran Matematika dengan pendekatan soal-soal terbuka (The Open Ended Approach)'. vol.1 No.1.

Krismanto, Al.,Widyaswara. (2003). PPPG Matematika, Beberapa Teknik Model dan Strategi dalam Pembelajaran Matematika,Yogyakarta: DEPDIKNAS. 